\title{
Hadji Murad by Decker-Schenk on Khabarovsk Stage: to the Problem of Formation of Artistic and Aesthetic Taste and Social and Moral Orientations of the Provincial Audience
}

\author{
Svetlana S. Syrvacheva* \\ Khabarovsk State Institute of Culture \\ 112 Krasnorechenskaia Str., Khabarovsk, 680045, Russia
}

Received 18.01.2016, received in revised form 27.02.2016, accepted 30.03.2016

\begin{abstract}
In Khabarovsk and a number of other provincial towns at the turn of the 19th-20th centuries, foreign and Russian operetta formed the basis of the mixed operetta and drama troupes' repertoire. One of the first Russian samples of this genre is analyzed in the article. Combining traditional musicological analysis with musical and sociological approach, the author attempts to establish a link between artistic and stylistic peculiarities of the popular work in the period under consideration - the operetta by I.F. Decker-Schenk "Hadji Murad", on the one hand, and its perception by the local artistic forces, audience and critics on the other. It is revealed that the ratio of "complexity" as a characteristic of high art and availability, typical of entertainment genres found by the composer and librettist, gave the provincial audience a feeling of belonging to art, at that theater became a symbol of the "civilized" provincial life.
\end{abstract}

Keywords: musical culture, musical theater, province, operetta, libretto, theatre audience.

DOI: 10.17516/1997-1370-2016-9-6-1499-1512.

Research area: art history.

Culture of the Russian province of the $19^{\text {th }}-20^{\text {th }}$ centuries is increasingly becoming the subject of the Russian science's interest. Rapid growth of musical local lore studies at present is determined by the steady interest in musical and theater life of the province. Through the example of separate provinces, territories and musical culture of the province in general, the researchers I.V. Belonosova, V.A. Zhadan, E.O. Kazmina, M.M. Kardynova, O.V. Ryabtseva, V.I. Yudina and many others studied a number of issues relating to the identification of specific (local) and common for musical and theatrical culture of the Russian province signs and principles of interaction between the capital and the provincial culture.

In the European part of Russia in the late $19^{\text {th }}$ century musical and drama theater "became not only a place of cultural communication of the provincial town dwellers, but also a kind of a symbol of the new, "civilized" provincial life" (Kardynova, 2010: 16-17). This tendency

(C) Siberian Federal University. All rights reserved

* Corresponding author E-mail address: fotin_s@mail.ru 
was manifested in the pre-Soviet period and in the cultural life of the cities of the Far East south, although the necessary conditions for the development of musical and theatrical culture were developed only by the end of the $19^{\text {th }}$ century. A significant contribution to the study of theater business and musical life of the cities of the pre-Soviet period located in the territory of the present Khabarovsk and Primorsky Krai and Amur Oblast, was made by I.V. Barashok, L.A. Wayman, S.Z. Grishko, A.S. Ivanov, V.A. Koroleva, T.V. Leskova, L.A Matveeva, V.P. Matveichuk, S.A. Monakhova, A.A. Pakhomov, E.A. Petukhova, V.A. Chernomaz, S.B. Chulkova, A.R. Shavanda and A.V. Shavgarova. Along with that, musical theater of Khabarovsk, one of major administrative and cultural centers of the Far Eastern region, has not been a subject of a special study yet.

When writing the article, the author based upon the conception of musical provinciology, proposed by V.I. Yudina. The researcher's ideas about the formation of a "single provincial musical space as a part of a nationwide Russian musical culture" (Yudina, 2013: 14), as well as about the "absence of a single, universal sample, a kind of a unified model of musical culture of a provincial town" if there are "general tendencies, that change specifically depending on territorial characteristics" (Yudina, 2013: 30) in the musical life of a town in the 18th - early 20th centuries are considered important. In terms of methodology a comment by V.N. Romanova and E.M. Levashev about the need of taking into account two tendencies - "centripetal (continuously implied comparison of the provincial phenomena of theatre art with the capital ones) and centrifugal (the most possible complete overview of the provincial opera life in particular)" is significant (Romanova, Levashev, 2004: 183-184)'.

In the present article the author attempts to consider the specific fact of musical and theatre life of the city of Khabarovsk - the repeated inclusion into the repertoire of the local theater groups the popular on the provincial scene of the early $20^{\text {th }}$ century composition - operetta "Hadji Murad" to establish a connection between artistic and stylistic peculiarities of the operetta, on the one hand, and the perception of the event by the audience and critics on the basis of materials published in periodicals. The samples of the operetta genre that are not staged for more than a century and which sheet music today are rare were chosen as an object of musicological analysis.

Musical and theatre life of Khabarovsk in the first decades of the $20^{\text {th }}$ century was represented, first of all, by operetta performances ("musical comedies") or performances of the theater of miniatures, which usually included shortened operetta (one act instead of three). The situation was very typical for small provincial towns of the early $20^{\text {th }}$ century. However, despite the obvious demand for the operetta genre in the theatre practice of those years, the composers were be looking for ways to develop national operetta for a long time. The statement published in the newspaper "Vechernyaya Moskva" on March 28, 1927 is typical: "Russian operetta is a difficult matter, if only because until now it simply was not represented" (Quoted from: (Vladimirskaya, 2009: 183).).

At the turn of the $19^{\text {th }}-20^{\text {th }}$ centuries the genre of operetta-mosaic that was represented as a montage of different in style, but always popular melodies of songs, romances, opera arias, etc. with the new text revealing the plot of the play was widely spread. "Gypsy romance" was especially loved by the audience, which, of course, was taken into account when composing mosaic operettas.

The problem of musical material borrowing in mosaic operettas was not anything but simple. In the published piano score with selected parts (romances, songs and choruses), included into the 
mosaic, the original name, the composer, both texts - the old and new ones - and their authors, the names of the actors who performed this scene in the mosaic were indicated. Similarly - directly, the source of musical material borrowing was indicated in the publications of the separate scenes of the mosaic by N.G. Seversky "New Gypsy Romances in Persons" (Davingof ${ }^{2}$ and Zimmerman $^{3}$ Publishing Houses). Along with that, there were other options of notes publication without mentioning the original name, composers, text authors, etc. Such are, for example, piano scores of the very popular at the turn of the $19^{\text {th }}-20^{\text {th }}$ centuries mosaic operettas by V.P. Valentinov. Sometimes it is difficult to determine the proportion of copyright material in these compositions. Along with that, creative activity of Russian operettas' authors was not always limited solely to compilation, there were attempts to create original compositions, even if they could not reach the level of classical European models of the genre.

The analysis of this kind of compositions is appropriate from two viewpoints.

Firstly, in a musical and sociological aspect, operetta, along with musical, vaudeville and comic opera belongs to the genres, which existence "was mostly dependent on the audience tastes and the role of administrative control was minimized" (Kudinova, 1982 253). It should be noted that there was not only the influence of the potential audience tastes on the process of compositions creation and choice of repertoire, but also the adverse effect - influence of the performed compositions on a theater spectator. In this context "the concept of artistic life of the city that makes a powerful formative influence on personality is important" (Gun, 2010: 48). According to G.E. Gun "artistic life of the city includes its cultural infrastructure, a certain level of cultural supply, implementing cultural policy, demand for cultural services, artistic consciousness of people who are characterized by various degrees of involvement into cultural life and other elements" (Gun, 2010: 49). Study of separate samples of the aforementioned genres up to detailed analysis allows characterizing the theater audience of the city.

Secondly, since in the course of the repertoire selection the level of the material complexity and the degree of its availability not only for the perception of the local audience, but also for it performance by the troupe forces could not but be taken into account, indirectly all the compositions included in the repertoire give evidence of the performers' professional capabilities. Comparative analysis of the several most popular operettas from the repertoire of different theatre troupes gives possibility to assess its creative potential.

I.F. Decker-Schenk ${ }^{4}$, Russian composer of Austrian origin, turned to the operetta genre repeatedly, in some cases giving preference to historical subjects or literary classics. "The Catalogue of Operettas and Related Genres of Music and Theater" compiled by N.I. Teterina included the following works of the author: "1812", "Tamara Beshlam-Cort's Castle", "Don Quixote", "Magic Tower", "Korredzhidor Secrets or Night Full of Adventures", "Phryne" and "Hadji Murad" (Istoriia russkoi muzyki, 10 (II), 2011). Almost all the musical-theatrical opuses of the composer appeared as a result of collaboration with librettist Z.B. Osetrov. The fact that musicaltheater works by Decker-Schenk were quite popular at the turn of the $19^{\text {th }}-20^{\text {th }}$ centuries is evidenced by the productions of his works on the stages of Moscow theaters", although only "Hadji Murad" stayed in the repertoire of the turn of the century. In the period from 1890 to 1917 there were eight first nights and the operetta revivals in the theaters of St. Petersburg and Moscow ${ }^{6}$.

The operetta genre researcher M. Jankowski, generally referring "Hadji Murad" to operettas 
created on the basis of borrowed material, does not comment on this issue: "The secret of success [...] mainly lies in the nature of the musical scene selection, in the process of their composing the love of the audience to the popular Caucasian folk melodies was properly taken into account. However, the main musical material of the operetta is based not on authentic folk materials, but on their distortion and vulgarization, in particular on the widely popular variety adaptations of Caucasian dancing themes and songs like "Gulimdjan" ..." (Jankowski, 1937: 366). Thus, the question of the author's text originality is directly connected with the problem of national peculiarity reconstruction in the operetta by Decker-Schenk.

The funds of the National Library of Russia contain "Hadji Murad" piano scores, published by P. Jurgenson ${ }^{7}$ and A. Bernardi's ${ }^{8}$ publishing houses. Although the dates of piano scores publication are not specified ${ }^{9}$, the Moscow edition contains the information about the fact that the operetta text was censored in September 1900. It is interesting that the publishing houses called Decker-Schenk's composition either operetta or opera. Thus, Odessa publishing house, informing about the operetta's first night date, wrote: "comic opera in three acts, staged for the first time in the St. Petersburg Maly Theatre on January 26, 1887". This permeability of borders between comic opera, operetta and vaudeville is determined historically ${ }^{10}$. And although topicality and sharp satirical humor are not typical of "Hadji Murad" by Decker-Schenk, as well as other Russian operettas of the turn of the century, nevertheless the external compositional characteristics and democracy of intonation dictionary bring this work together with the genre of comic opera. In addition, the composer's attribution of the genre was influenced by the issue of the fee: “... according to the laws of the Russian Empire, the largest fee was received by composers, who composed the original operas that did not have any prototypes in relation to drama. Operettas were significantly less paid" (Istoriia russkoi muzyki [2011]. 10 (II), 987).

Operetta's name refers the listener to the events of the Caucasian War of the $19^{\text {th }}$ century. Hadji Murad is a real historical figure that inspired L.N. Tolstoy, a decade after the premiere of the operetta by Decker-Schenk, to create one of his Caucasian stories ${ }^{11}$.

Undoubtedly, Tolstoy's masterpiece and Decker-Schenk/Osetrov's work are the phenomena of different scale. To undertake such a comparison would mean deliberately put at a considerable disadvantage not only this operetta, but almost any composition of the light genre. It is obvious that the goals set to the great Russian writer and considered by the authors of the operetta, did not coincide. "... Tolstoy in the true sense did scientific and historical work - analysis and criticism of the "primary sources", comparison of the facts and eyewitnesses accounts, combining them in a realistic synthesis. Tolstoy's purpose is clear - to achieve the greatest possible factual and chronological accuracy" (Tunimanov, 2011: 25).

It is obvious that factual accuracy is not the strong side of the libretto. From the operetta we do not learn that Avar Hadji Murad (in the list of actors - "Lezghian Dzhigit") was a famous naib of Shamil. The operetta's action, according to the piano scores ${ }^{12}$, takes place at the late $18^{\text {th }}$ century (while the historical Hadji Murad was born in the second decade of the $19^{\text {th }}$ century). The librettist purpose is to tell about one entertaining "episode" from the life of the peoples of the Caucasus, through which example it would be possible to demonstrate their own idea of the "Caucasian customs" ${ }^{13}$, and make a historical figure - the glorified warrior - a participant of this episode, for greater significance and attractiveness necessarily combining the episode in accordance with the laws of light musical and theatrical genre with the love affair ${ }^{14}$. Depicting everyday life of 
the residents of a Georgian village, namely - the noisy feasts with pompous toasts in his own honor ("Glory to us, death to the enemy!"), arranged each time on the occasion of the return from the frequent military campaigns, the night's recreation organization for the male and female halves of the populations, etc., Osetrov and Decker-Schenk found application to the biographical information about Hadji Murat that was at their disposal. The authors used such a well-known quality of this hero as his legendary ability to remain invincible under any circumstances. Projecting this characteristic of real Hadji Murad to the image of the operetta's character contributed to quite a happy ending in accordance with the canons of the genre and the audience's expectations: the main character narrowly escapes death in the enemy's camp. Such an "adapted" operetta's Hadji Murad is represented not as an invincible warrior-strategian, but as an unlucky kidnapper of Georgian prince Durmishkhan's bride, who in the end turned out to be her brother. The Tolstoy's story character with his tragic fate is versatile.

Z.B. Osetrov's libretto, not reaching any high degree of artistic excellence, caused quite a strong criticism of M. Jankowski, what is partially determined by orientations concerning pre-Soviet culture, adopted in Russian musicology of the $1930 \mathrm{~s}^{15}$. The libretto's text is not very poetic and contains stylistic errors as well. When connecting the words with the music new irregularities arise. Thus, in one of the sections of the first act's final there is a discrepancy between the metric accent in tact and stress in the word $^{16}$ (7 (750-751) see Musical Example No 1.).

As for the content, quite a long first part (319 bars) is a detailed drinking song with the choir and soloists participation, where the calls "to make noise" and "carelessly carouse" are continuously repeated, depicting the image of brave and reckless warriors. A very peculiar humor is connected with the use of the technique of Russian indeclinable speech and funny expressions' parody. In the part of dukhan owner ${ }^{17}$ Davydka, who was Armenian, the phrase "yoursmine, yours-mine, vai-vai-vai-vai! ${ }^{18}$ " designed to give a comic effect, repeatedly appears.

Could the above mentioned imperfections of libretto operetta "Hadji Murad" alert the audience? Probably, they could not. In general, librettos' texts in Russian operettas and the socalled adaptations (of foreign compositions for the Russian scene) were not characterized by high quality. The harsh verdict was given by $\mathrm{M}$. Jankowski: “... the experiences of the original operetta creation almost without exception, represent samples of low-grade literary garbage, or, in rare cases, rise to the level of average craft products" (Jankowski, 1937: 363). A part of the audience, especially in the province at that time got used to this situation, and another part probably did not want more. For comparison a fragment of the text of the operetta "The Parrot and the Bridegroom" (from No. 2) will be given. The operetta is significantly inferior to "Hadji Murad" in all criteria, but, nevertheless, according to the correspondent of "Priamurskaya Zhizn"”19, liked by the Khabarovsk audience, despite the "absence of the parrot": "We came here with my nephew. / Nobody knew us, indeed, / We found the road ourselves / To see it! / We gradually needed / To know it all necessarily. / If there is anything / Something of the kind. / That one, that one, that one! ..." ${ }^{20 .}$

In the operetta "Hadji Murad" the word is mainly intoned in the vocal part, prosaic speech is used in the form of one or two phrases, preceding some vocal parts. The word recorded in the vocal part did not allow the actors to improvise and much less, move to the widely spread at that time farcical style of play. Perhaps such a "dominating" importance of the music beginning that almost did not leave the space for the spoken dialogues, was one of the reasons for the perception of "Hadji 
Murad" by the audience and the actors themselves as a "serious" representative of its genre. In this context the announcement published in Vladivostok newspaper "Dalekaya Okraina" on March 21, 1917 [7, p.7], in which operetta "Hadji Murad" was awarded by the epithet "classical", which, as a rule, accompanied announcements about the performance of the French or Viennese operettas, is indicative.

Decker-Schenk is also classical in his aspiration to stick to the current line systems: for two characters - Zurab and Davydka - already in the line's piano score both a comedian and low comedian are marked respectively. Hadji Murad (mezzo-soprano or baritone) and Ketevan (soprano), according to this system, can be classified as characters acting as the hero and the heroine.

As for composition "Hadji Murad" is threeact operetta, which corresponds to the strong tradition of the genre. The composer's concern about giving the whole structure harmony and balance is evident. Every act is climaxed by the finale, at that the scale of the finale, as well as the quantity of parts in the act, is gradually reduced from the first to the last act. If the first and the second acts, each of that include seven parts, are finished by the extended finales (the first act finale contains 816 bars, the second one -454 bars), a small third act, consisting of three parts, finish the modest in its size finale (172 bars) and following it Lezgian dance that was drawn by the composer separately (all together they occupy 229 bars). "Introduction" (No. 1) that balances the composition of the entire operetta has similar to the finales structure (free alternation of choral and solo sections). Introduction to the first act and the finale of the third act are a kind of framing for the two big scenes - the finales of the first and the second acts ${ }^{21}$.

Different forms of utterances are used in the operetta: solo (aria, arietta, ballade, romance and verses), ensemble (duet) and choral, there are instrumental sections and ouverture. Solo form is most widely represented. The main characters are endowed with arias, that are compositional centers of the operetta - these are Hadji Murad's (No. 12) and Ketevan's (No. 11) arias from the second act; in the third act Ketevan performs another aria (with the chorus, No. 16), anticipating the operetta finale. The rest of the solo forms, smaller ones, are in the first act: these are Hadji Murad's ballad (No. 2), Ketevan's arietta (No. 3) and Ketevan's romance (No. 4). The verses are performed by the secondary characters - by Zurab (No. 9) and Davydka (No. 10). Solo parts also include spectacular Ketevan's gavotte from the second act (No. 13).

Almost complete absence of ensembles opposes to such an abundance of solo parts. The protagonists' duet (No. 5) is the only ensemble in the operetta. Indicated in the piano scores as "ensemble" (but with the clarification - "Hadji Murad's and the chorus' aria") No. 12 does not involve the soloists' joint singing and, in this connection, it is actually not an ensemble ${ }^{22}$. Some resemblance of terzetto performed by Hadji Murad, Durmishkhan and Zurab takes place in the finale of the second act (m. 363-387).

Such an evident disproportion in the solo parts quantity, performed by two main characters and ensemble at first glance may indicate of the fact that the composer could not use of techniques of ensemble writing. On the other hand, due to such a distribution, the operetta can be vocally "performed" by two soloists with serious training, what is important for its performance in a province. The composer's aspiration to take into account performing forces of provincial troupes can be seen in this disproportion. The presence of verses, these "little arias", that are "given to the ordinary heroes" (Kudinova, 1982: 16), does not contradict to our conclusion. 
The extensive use of choral singing, which gives it a touch of opera, is a specific feature of operetta "Hadji Murad". The chorus is involved in nine of the seventeen parts, although almost all of them are not only choral. The exceptions are No. 6 and 15 that are indicated in the piano scores respectively as "Magdana and Women's Chorus" and "The Chorus of Georgian girls and Magdana”. In No. 6 short 12-bar Magdana's recitative precedes to a miniature 17-bar chorus that sounded earlier in No. 3. In other cases, the choral episodes, with all the significance of their role in the operetta by Decker-Schenk, are either connected with a solo part (for example, "The chorus of women and Ketevan's arietta", No. 3), or alternating with the other sections are parts of the finales. Complexly evolved forms are not represented, major scenes are kaleidoscopic. Rondo-similarity acts as a fastening point, for example, in "Introduction" (No. 1). Sometimes unison choral singing is used; mostly the choruses are small, with a sustained chord constitution (mostly three- and four-parts) and rhythmicallysynchronous movement of all the voices.

This type of texture, typical of operetta and partially of opera choruses is far from both the original Georgian polyphony, peculiar to Kartalino-Kakhetian drinking or long life songs, and the traditional folklore of West Georgia branch. Emerged within the urban folklore, as well as solo genres (romances and songs), Georgian polyphony of the more recent origin (the second half of the $19^{\text {th }}$ century), was strongly influenced by the Russian and West European music. This is evident, for example, in the use of harmonic modes, absence of runs and movement of the upper voices in parallel thirds. Such is in musical and stylistic relation "Mravalzhamier" chorus from the operetta by Decker-Schenk (No. 1, t. 197-212: see musical example No. 2.).

On the basis of the abovementioned borrowings and stylistic analogies it is impossible to talk about the composer's address to the musical folklore of the Caucasian peoples as the thematic source in an operetta. Rather, it is referred to a superficial imitation of some typical forms as well as inclusion of the samples of popular genres to the operetta - two Lezgian dances (No. 7, t.151-182 and the dance that finishes the opera), shaitan verses of "Gulimdzhan's" Davydka and a lingering drinking song "Mravalzhamier" (Georgian "Long Life" song). Some parts, for example, such as the chorus of Georgian girls (No. 15), begin with the typical of Georgian folklore repetitive fifths in bass. However, such characteristic of Georgian folklore, as richness and diversity of rhythm, the use of diatonic modes, arioso-recitative style of the vocals parts and abundance of ornamentation in the operetta by Decker-Schenk are not recreated. However, in some parts, particularly in the first Ketevan's aria (No. 11) which remote prototype can be a Georgian town song, the composer uses runs. Georgian song was formed under the influence of, among other genres, Russian town romance as well, and therefore it is not by chance that in this Ketevan's aria the gypsy mode, characteristic of both genres, is used.

T.N. Kudinova's idea that "Operetta, first and foremost, meets the emotional needs of listeners and viewers, without involving in the sphere of complex ideological problematics" (Kudinova, 1982: 37), is also true for the composition by Decker-Schenk. Operetta's action takes place in the context of the confrontation between Georgians and Lezghins (more precisely, Lezghins' raids and Georgians' defensive actions), however, at the level of intonation dramatic composition the conflict was not detected. The finale of the second act in this respect is indicative: Georgian chorus "We passed the ravines and cliffs ...", that opens the finale (t. 16-60), is literally repeated by their enemies Lezghins, what is more, in the same tonality (d-moll), although with new words: 
“The sky was blotted out by clouds..." (t. 144$163 \mathrm{~m}$.). The events taking place in the finale of the second act (the search of the escaped from Lezghins Ketevan and Hadji Murad captivity by Georgians), are performed against the background of the storm, the gloomy color of the chorus part in the accompaniment is supported by chromatic passages and harmonies of the reduced introductory seventh chord. The desire to convey the state of emotional tension and misgiving experienced both by Georgians and Lezgins allowed the composer to use one and the same musical material which, in terms of genre, is close to the march and does not have a specific national coloring. In general, the everyday genres: march, waltz, Lezgian dance and romance were the basis for most parts of the operetta.

In Khabarovsk print media of the 1900-1910s all information about "Hadji Murad" performance to the local audience preserved. A valid argument in favor of the now-forgotten operetta is the fact that this operetta was chosen by music and theater troupes for a benefit event of a particular actor.

The first mentioning of the operetta refers to 1905: in connection with the tours of the brilliant "I.M. Arnoldov's Harbin Operetta Troupe" in Khabarovsk "Priamurskie Vedomosti" published its announcement. About "Hadji Murad" it was reported that it was "the operetta in three acts of the customs of Caucasian life" ${ }^{23}$, chosen for D.B. Tumansky's benefit evening, who had comic roles in the troupe.

Three years later (in May 1908) the operetta was performed in Khabarovsk again by "the operetta troupe managed by the actor of Moscow and St. Petersburg theaters A.D. Pisarev to benefit actor Rostovtsev. In the announcement published in the newspaper "Priamur'e" it was reported: "Tomorrow in Mateus Theater a benefit evening of the favorite actor of the Khabarovsk audience, the talented actor Rostovtsev, who is truly one of the best actors of the troupe, is taking place.
The actor for whom benefit performance is given, stages the famous operetta "Hadji Murad" where he is having a very interesting role of that requires much talent, and Rostovtsev' interpretation of the role is of profound interest, as he endows it with a number of new original characteristics" ${ }^{24}$. Unfortunately, the author did not specify the original characteristics that were introduced by the actor to the interpretation of the dukhan owner Davydka's image.

The only preserved, although extremely brief review of performance of the operetta by DeckerSchenk in Khabarovsk relates to the performance of 1918 by the operetta troupe managed by the actor and director A.S. Rossov. This time the protagonist was in the focus, "on December 19 in Mateus Theater operetta "Hadji Murad" and the scene of the duel from the opera "Eugene Onegin" were staged. Due to participation of the best actors of the troupe and good mood their operetta and the scene from the opera were a success. Hadji Murad in A.S. Rossov's performance was especially good. Such bright and colorful performances had not been seen in Khabarovsk for long. Magnificent Davydka - Mr. Avtokratov and Mr. Grey were a success [...]. "Hadji Murad" production is characterized by the rich scenery, costumes and the whole skillfully and tastefully created ensemble. There was a lot of audience. Espe." ${ }^{25}$

Reviews in the press, especially in the provincial one, as a rule, were not characterized by objectivity, impartiality and much less by professional approach. Another factor complicating the research work with this type of source is aspiration of the troupe leaders to give the best advertising of the upcoming performances. For this purpose, different kinds of effective phrases were often used. Perhaps, focus on catchy advertisements or common ignorance caused the appearance of incorrect information in printed media that in December 1918 "Hadji 
Murad" (was going to be) shown "in Khabarovsk for the first time" ${ }^{26}$.

And, nevertheless, announcements and reviews on "Hadji Murad" performances in Khabarovsk evidence of the fact that actors, audience and critics gave the operetta not only positive assessment, but also considered it to be a very decent compositions, what, in particular, allowed to combine it with a fragment from the opera by P.I. Tchaikovsky, performing in one evening so different in their artistic quality compositions. Probably, the main incentive here was the ability to balance, to "compensate" negative emotions from the duel scene by the light operetta. In such a contrasting combination of styles and genres a kind of manifestation of concern for the audience can be seen.

In connection with "Hadji Murad" performance the similar picture was in nearby Vladivostok. The first performance out of three that took place, as evident from the chronicle of the cultural life of the city of the post-revolutionary period, was marked by the benefit evening of the of "V.G. Darov's Operetta" troupe leader (Koroleva, 1998: 111) in July 1920. The announcement of an earlier performance (21 March 1917), when the operetta was called "classical", has been previously mentioned. And then "Hadji Murad" was given as a morning performance, according to the newspaper "Golos Rodiny" dated January 7, 1921 (Koroleva, 1998: 140).

Comparative statistical analysis of the data contained in chronograph "Theatrical Life of the Province" (1890-1917) [5] concerning the number of operetta "Hadji Murad" performances lead to the conclusion of a special sympathy of the Far Eastern audience to this composition (Blagoveshchensk is mentioned 6 times, Vladivostok - 4 times and Khabarovsk, probably, is not mentioned due to the lack of the processed information). Among other cities of the Russian Empire it is possible to emphasize Arkhangelsk (mentioned 3 times). Cities, with very intensive musical and theatrical life (Kiev, Kazan, Odessa, Tbilisi and others) are mentioned in the chronograph primarily in connection with the opera performances.

For any phenomenon evaluation in the field of culture and art it is common practice to use the criteria that could best uncover its meaning. As a rule, when evaluating musical and theatrical works the following criteria are taken into account: originality of artistic conception; the depth of its implementation; technical skills of the composer and librettist; having the variety of (opera, operetta) forms and some others. Despite the fact that operetta "Hadji Murad" standing was strong not in all the above criteria, it is obvious that it occupied a special niche in the artistic life of the city in the $1900-1910$ s, following all the qualities of the spirit of time and being warmly received by the audience and highly valued by the performers.

From the author's point of view, I.F. DeckerSchenk and Z.B. Osetrov at the time managed to find a good balance of the "complexity" as an attribute of high art, and availability inherent to entertainment genres. In other words, it is light music that nevertheless gave the feeling of belonging to art, thus becoming the symbol of the “civilized" provincial life. Probably T. Adorno's words concern this phenomenon: "Until the late 19th century light music was still possible with keeping preserve appearances. And a phase of its aesthetic decline coincides with a final and irrevocable refusal of both spheres (serious and light music - S.S.) from each other" (Adorno, 2008: 27). It can be said that the role of the opera house in these conditions was partly performed by the operetta theater.

This conclusion is not surprising or paradoxical, it is confirmed by the statistics of performing the samples of serious and light repertoire in the city of Khabarovsk, almost 
complete absence of operas in the poster boards of music and theater troupes of the first decades of the $20^{\text {th }}$ century, as well as a very qualified welcome of the Italian opera troupe that toured in the city in 1905 with opera repertoire. "In the process of adaptation to the realities of provincial life, the cultural form of operetta adopted a number of the dominant features of the Russian province culture, such as substantial proximity to the desired representations of the population of the perfect and desired, as well as optimistic tone, which explains its specific socio-cultural and aesthetic significance for the Russian province in the historical period under study" (Ryabtseva, 2006). As a result, the drawbacks of Decker-Schenk's music and the libretto's text could not obstruct an important advantage: it is in these works where the tastes of the provincial audience, the possibility of artistic compositions of the provincial troupes and the desire of the intellectual listeners and viewers to touch the art were taken into account.

Musical examples:

Musical Example No.1

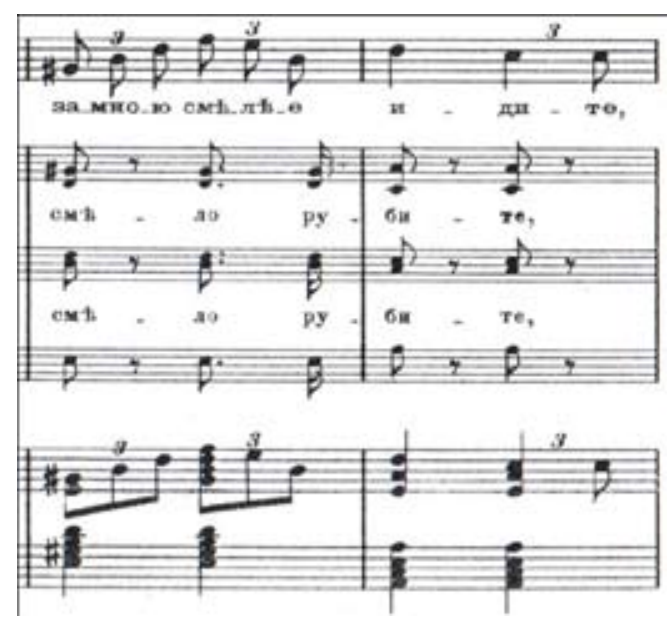


Musical Example No.2

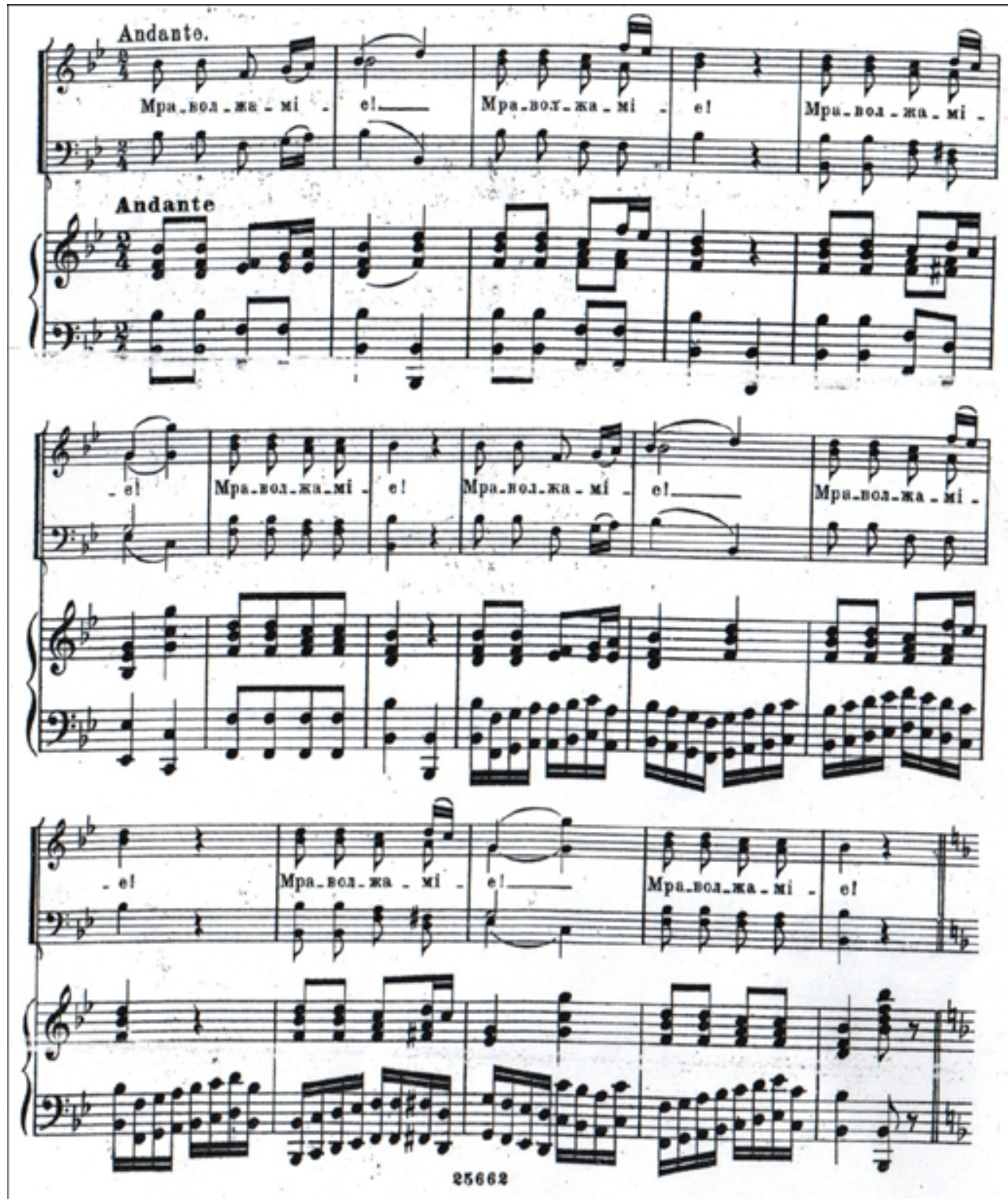

Taking into consideration the characteristic of the second tendency, the notion of "culturological chronotop of the theatre life of province" is used (Romanova, Levashev, 2004:184).

2 Novye tsiganskie romansy v litsakh. Muzykal'naia mosaika N.G. Severskago. Otdel'naia NN iz operetty. Sobstvennost' izdatel'stva "Nikolai Khristianovich Davingof" [New Gypsy Romances in Persons. Musical Mosaic by N.G. Severskai. Separate NN from the Operetta. Property of "Nikolai Khristianovich Davingof" Publishing House]. St. Petersburg [Date of publication is not specified).

3 Novye tsiganskie romansy v litsakh. Operetta N.G. Severskago. Izdanie "Tsimmerman”. Dozv. Tsenz. Spb 4 oktiabria 1890 g. [New Gypsy Romances in Persons. Operetta by N.G. Severskai. "Tsimmerman" Publishing House. Censorship Approval. SPb. 4 October 1890]. [Date of publication is not specified].

4 "Ivan Fedorovich Decker-Schenk (1825-99) - Russian guitar player, composer and educator. [...] From 1861 lived in Russia. Gave concerts as a guitar player, mandolin player and a singer. [...] The author of comic operas, operetta "Hadji Murad" (1887, Saint-Petersburg) and others, as well as romances, compositions for 6- and 7-string guitar". Big Encyclopedic Dictionary, "Music". M., 1998.

Operetta "Tamara's Castle" was staged in The Moscow Hermitage Theatre (1890, produced by M.V. Lentovsky); in 1812 in Paradise Moscow Theatre (1890); "Phryne" in Saint-Petersburg Theatre "Arcadia" (1893). 
6 According to the data of chronograph "Theatre life of Saint-Petersburg and Moscow" the operetta was staged in Maly Theatre (Saint-Petersburg, 1890); Paradise Theatre (Moscow, 1890); garden theatre "Aquarium" (Moscow, Theatre "Buff", theatre manager S. Omon, 1897); in the same place (1898); in the Nemetti Theatre (Saint-Petersburg, Operetta troupe, theatre manager Tumpakov, 1899); Theatre "Buff” (Saint-Petersburg, 1905); Ekaterininsky Theatre (Saint-Petersburg, 1907); the Palace Theatre (Petrograd, 1915) (Istoriia russkoi muzyki, 10(V), I, 2011).

7 Hadji Murad. Operetta in 3 Acts. Music by I. Decker-Schenk. Lyrics by Z. Osetrov. Moscow. Leipzig: P. Jurgenson Publishing House [Date of publication is not specified].

8 Hadji Murad. For Singing with the Piano. Music by I.F. Decker-Schenk. Libretto by Z.B. Osetrov. Odessa: A. Bernardi Publishing House [Date of publication is not specified].

9 "The Catalogue of Operettas and Related Musical and Theatrical Genres" made by N.I. Teterina, contains reference to three editions of "Hadji Murad" by I.F. Decker-Schenk: "1) M., 1900 (GIMMK); 2) M.- Leipzig: Jurgenson, 1900 (RSL); 3) Odessa: A. Bernardi's Music Store, 1888 [Comic Opera in 3 Acts. (From Customs of the Caucasus)] (RSL)" (Istoriia russkoi muzyki, 10(V), II, 2011, 1157-1558).

10 "Comparing operetta with the modern comic opera, it is easy to observe their dissimilarity," - writes T.N. Kudinova. "But it is worth recalling the democratic opera of the $18^{\text {th }}$, its topicality, satirical spirit, vivid household scenes, comic technique, songs with easily recognizable intonations of the urban folklore, arias in the dancing rhythms, the principle of alternation speech with singing, thus it becomes clear that the operetta performed as a direct descendant of this comic opera. We can say that operetta took over its role in the new historical epoch and, depicting the manners of another time, it spoke in other (contemporary to it) intonations and rhythms" (Kudinova, 1982: 36-37).

11 L.N. Tolstoy was writing his story "Hadji Murad" from 1896 to 1904.

12 Hereinafter the analysis is made based on P. Jurgenson's edition.

13 Recall that it was conveyed by a remarque in the piano score (see footnote 9 ).

14 In the genre of operetta the classical example of "a frivolous story," developing on the background of historical turmoil was "The Beggar Student" (Der Bettelstudent, 1882) C. Millöcker.

15 "The operetta's libretto impresses with its meanness and monstrous illiteracy. And, nevertheless, "Hadji Murad" stayed on the Russian operetta stage for nearly thirty years" (Jankowski, 1937: 366).

16 From our point of view such rhythmic violations in verse are random; the author does not see an artistic effect in the accents mismatch.

17 The owner of dukhan (i.e. a tavern, a pub or a stall in the Near East).

18 Ketevan's aria and girls chorus, 16 (6-10).

19 Priamurskaya Zhizn', 1917, 2 October, P. 3.

20 Popugai i zhenikh. Operetta v 1-m deistvii L.L. Pechorina. Izdanie Stolichnogo Teatral'nogo Izdatel'stva “TEATRAL'NYIA NOVINKI" [The Parrot and the Bridegroom. Operetta in 1 Act by N.N. Pechorin. Moscow Theatre Publishing House "TEATRAL'NYIA NOVINKI"]. Nikolaevskaia, 8. Petrograd [Date of publication is not specified], 2.

21 Compare with the compositional structure of the operetta by J. Strauss "The Gypsy Baron" (Der Zigeunerbaron, 1885): the first act consist of seven parts, including the finale ( 760 bars); the second act - six parts (the length of the finale is 440 bars); the third - five parts (the length of the finale is 65 bars). There is the same tendency of the proportions ratio. The analysis is made on the basis of the piano score: Jogan Shtraus. Tsygan baron. Operetka v 3-kh deistviiakh iz povesti M. Dzokai, I. Shnitser. Perevod s nemetskogo M.G. Iaron. Dlia penia v dve ruki. Sobstvennost' izdatelia. S.Peterburg, A. Bitner [Johann Strauss. The Gypsy Baron. Operetta in 3 Acts from the Story by M. Jókai and I. Schnitzer. Translated from German by M.G. Yaron. For Singing in Both Hands. Property of the Publisher St. Petersburg, A. Bitner] [Date of publication is not specified].

22 Regarding actual avoidance of ensemble singing by specifying presence of the ensemble scenes in the piano scores "Hadji Murad" by Decker-Schenk is not an exception among the works of the period under study. A similar example of the ensemble is a quartet (No. 17) from the operetta by V.P. Valentinov "Priestess of Fire": solo and unison singing sound for 48 bars (from 56), another 4 bars are occupied by the instrumental introduction. The same tendency is observed in the "Duet of Kisses" (No. 6) and other ensemble parts from the most popular operetta by S. Jones "The Geisha" (1896).

23 Priamurskie Vedomosti, 1905, 14 December. P. 1.

24 Priamur'e, 1908, 1 May. P. 4.

25 Priamur'e, 1918, 22 December. P. 3.

26 Priamur'e, 1918, 19 December. P. 1.

\section{References}

Adorno, T. [2008]. Izbrannoe: Sotsiologiia muzyki [Selected Works: Sociology of Music]. M, Rossiiskaia politicheskaia entsiklopediia (ROSSPJeN), 448.

Vladimirskaya, A.R. [2009]. Operetta. Zvezdnye chasy [Operetta. Hours of Triumph]. SPb., 288.

Gun, G.E. [2010]. Teatr kak faktor hudozhestvennoi zhizni goroda: sotsiologicheskii aspekt [Theatre as a Factor of Artistic Life of the City: Sociological Aspect], In Teatr v zerkale problem obrazovaniia [Theatre in the Mirror of Education Issues]. Materials of Town Research and Practice 
Interuniversity Conference within the Frames of the $4^{\text {th }}$ International Festival of Opera Arts "Viva opera"! Magnitogorsk, April, 2010. Magnitogorsk, MGTU, 48-53.

Istoriia russkoi muzyki: V desiati tomakh [History of Russian Music: In Ten Volumes] [2011]. 10(V): 1890-1917, Khronograf, I. M, Iazyki slavianskikh kul'tur, 964.

Istoriia russkoi muzyki: V desiati tomakh [History of Russian Music: In Ten Volumes] [2011]. 10(V): 1890-1917. Khronograf, II. M, Iazyki slavianskikh kul’tur, 2011, 1232 .

Kardynova, M.M. [2010]. Provintsial'nyi teatr v obshhestvennoi zhizni Rossii vtoroi poloviny $X I X$-nachala XX vv.: na materialakh Nizhegorodskoi i Kazanskoi gubernii [Provincial Theatre in the Public Life of Russia of the Late 19 $9^{\text {th }}$ - Early $20^{\text {th }}$ Century: Exemplified by Nizhny Novgorod and Kazan Governorates]: abstract of the dissertation for the scientific Degree of the Candidate of Historical Sciences, Nizhnii Novgorod, 28.

Koroleva, V.A. [1998]. Khronika kul'turnoi zhizni Vladivostoka 1917-1922. Muzyka. Teatr. Kino [Chronicle of the Cultural Life of Vladivostok in 1917-1922. Music. Theatre. Cinema]. Vladivostok, Izdatel'stvo DVU, 196.

Kudinova, T.N. [1982]. Ot vodevilia do miuzikla [From Vaudeville to Musical]. M, Sovetskii kompozitor, 175.

Raku, M.G. [2011]. “Novyi potrebitel”” v sovetskoi muzykal'noi kul'ture 1920-kh godov: k postanovke problemy "implitsitnogo zritelia" ["New Consumer" in Soviet Musical Culture of the 1920s: Setting the Problem of "Implicit Spectator"], In Sociologiia muzyki: novye strategii v gumanitarnykh naukakh [Sociology of Music: New Strategies in Humanities]. M, Kompozitor, 250-262.

Romanova, V.N., Levashev, E.M. [2004]. Muzykal'nyi teatr v provincii. Obshhaia kharakteristika [Musical Theatre in Province. General Characteristic], In Istoriia russkoi muzyki $v$ desiati tomakh [History of Russian Music: In Ten Volumes]. 10(B), 1890-1917. M, Muzyka, 183-209.

Ryabtseva, O.V. [2006]. Teatr operetty v usloviiah rossiiskoi provintsial'noi' kul'tury kontsa XIX - nachala XX veka: kul'turno-istoricheskii analiz: avtoref. dis. ... kand. kul'turologii [Operetta Theatre under Conditions of Russian Provincial Culture of the Late 19th - Early $20^{\text {th }}$ Centuries: Cultural and Historical Analysis: abstract of the dissertation for the scientific Degree of Candidate of Culturology]. M. Available at: http://www.dissercat.com/content/dinamika-russkoi-provintsialnoikultury-v-usloviyakh-istoricheskikh-transformatsii-rossiisko/

Tunimanov, V.A. [2011]. Kavkazskie povesti L.N. Tolstogo. Predislovie k izdaniiu: Tolstoi L. Hadzhi-Murat: Povesti [The Caucasus Stories by L.N. Tolstoy. Foreword to the Edition: Hadji-Murad: Stories]. SPb, Azbuka, Azbuka-Attikus, 5-34.

Yudina, V.I. [2013]. Muzykal'naia kul'tura rossiiskoi provintsii: ot zarozhdeniia do nachala XX veka: avtoref. dis. ... doktora kul'turologi [Musical Culture of the Russian Province: From Origin to the Early $20^{\text {th }}$ Century: abstract of the dissertation for the scientific degree of Doctor of Culturology]. $\mathrm{SPb}, 48$.

Jankowski, M. [1937]. Operetta. Vozniknovenie i razvitie zhanra na Zapade i v SSSR [Operetta. The Genre Origin and Development in the West and the USSR]. L.-M., Iskusstvo, 456. 


\section{к проблеме формирования \\ художественно-эстетического вкуса \\ и социально-нравственных ориентиров \\ провинциального зрителя}

«Хаджи-Мурат» Деккер-Шенка на хабаровской сцене:

\section{С.С. Сырвачева}

Хабаровский государственный институт культуры Россия, 680045, Хабаровск, ул. Краснореченская, 112

В Хабаровске и ряде других провиничильных городов на рубеже ХІХ-ХХ веков зарубежная и отечественная оперетта составила основу репертуара смешанных опереточнодраматических трупп. В статье анализируется один из первых отечественных образиов этого жанра. Совместив традиционный музыковедческий анализ с музыкально-сочиологическим подходом, автор предпринимает попьтку установления связи между художественностилистическими особенностями популярного в рассматриваемый период сочинения - оперетты И.Ф. Деккер-Шенка «Хаджи-Мурат», с одной сторонь, и ее восприятием местными артистическими силами, публикой и критикой, - с другой. Выявлено, что найденное композитором и либреттистом соотношение «сложности», как атрибута высокого искусства, и доступности, свойственной развлекательным жанрам, давало провинциальному зрителю ощущение приобщенности к искусству, при этом театр становился символом «цивилизованной» провинциальной жизни.

Ключевые слова: музыкальная культура, музыкальный театр, провинция, оперетта, либретто, театральная публика.

Научная специальность: 17.00.00-искусствоведение. 